\title{
Vulnerable Workers in an Emerging Middle Eastern Economy: what are the implications for HRM?
}

\author{
Julia Connell $^{\mathrm{a}}$ and John Burgess
}

Curtin Business School, Curtin University, Perth, Western Australia

\begin{abstract}
Dubai offers an example of the contradictions and tensions surrounding a development model based on migrant labour, foreign investment and a segmented labour market which has led to the exclusion of large segments of the labour force from basic forms of labour standards and protection. Unlike many other developing economies, Dubai does not possess large labour surpluses and a large informal labour market, but instead has constructed its labour market around distinct divisions within the workforce. Consequently, it is argued that, in line with building and developing civil institutions in the Middle East, there are several urgent labour reforms that are required to address the migrant workforce vulnerability and exclusion. This paper outlines the implications of these proposed reforms for human resource management in Dubai, offering a framework that encompasses the responses required of strategic international HRM in combination with recommended HR practices that can assist in reducing worker vulnerability.
\end{abstract}

Keywords: HRM, labour market, labour regulation; migrant workers, Middle East.

\section{Introduction}

The 2008 British Trade Union Council's (TUC) Commission on Vulnerable Employment described vulnerable employment as 'precarious work that places people at risk of continuing poverty and injustice resulting from an imbalance of power in the employer-worker relationship’ (p.11) further stating that migrant workers are one of the most at-risk groups. Towards their goal of pursuing full and productive work for all, the ILO pursues a Decent Work Agenda which comprises four interrelated areas: respect for fundamental worker's rights and international labour standards, employment promotion, social protection and social dialogue in recognition of reducing what are referred to as decent work deficits (ILO 2012). This paper focuses on how industrial relations and human resource management policies and practices may assist in reducing some of the decent work deficits that result in worker vulnerability in Dubai. 
Dubai, in common with most of the Arab world, employs expatriate workers on short-term employment contracts, and this short-term approach and lack of employment security can make it hard for organizations to generate the degree of employee commitment they require (Khan 2010). Al-Rajhi et al. (2006) in their study of Saudi Arabian human resource (HR) systems argue that HR has an important role to play in facilitating the successful cultural and work adjustment of migrant workers in order to enhance their productivity and well-being. A potential dilemma is the adoption of HR systems in a Middle Eastern context, which have been developed within western environments. Consequently, there is a need to understand regional or country-specific phenomena so as to help evaluate the potential of regionally specific initiatives (Budhwar and Mellahi 2006).

Dubai is one of 7 emirates in the United Arab Emirates (UAE). The emirate of Abu Dhabi is the capital of the UAE and the largest of the 7 emirates, and Dubai is the second largest (Abdulla, Djebarni and Mellahi 2011). In comparison to other regions, the Middle East has a dearth of literature on human resource management (HRM) and there are no apparent HR best practices in the Arab Middle East (AME) region (Afiounia, Karama and El-Hajj 2013). Budhwar and Melhali (2006) noted that, following a thorough literature search, they found no evidence of any systematic analysis that could represent a comprehensive picture of the dynamics of HRM in the Middle East. It may be expected that the challenges of competing in a global market would stimulate an interest in HRM practices among Arab business leaders (Moideenkutty, Al-Lamki and Murthy 2011) and certainly more studies have recently begun to emerge from the region. For example Rees, Mamman and Bin Braik (2007) studied Emiritization as a Strategic HRM change initiative while Afiounia et al. (2013) investigated whether an HR value proposition model exists in the Arab Middle East. In addition Al-Hamadi et al. (2007) found that the major factors influencing HRM in Oman were religion (Islam), civil service laws, the expatriate workforce and social elites (Omanis who were educated abroad).

Over the past few decades Dubai has adopted an economic development model which has been described as strongly pro-business, emphasising market liberalism, economic openness and globalisation, thus taking a different approach to the economic models applied in other countries in the Gulf Cooperation Council (GCC) (Hvidt 2011). 
The 'Dubai Model' has relied on importing labour, both skilled and un-skilled on a significant scale, creating an economic infrastructure base and support industries, where previously very little existed. Unlike many developing economies, Dubai began its growth trajectory without surplus labour, or indeed without a labour force that could meet the needs of a fast growing economy. Lacking an indigenous skilled workforce, Dubai has been compelled to import an expatriate labour force (Connell and Thorpe 2010). The inflow of migrant labour has been so extensive that the UAE comprises national minority states where locals make up a small minority of the population (Koji 2011). Professionals and managers helped to put public services in place and build the social and business infrastructure of the modern state, while unskilled and semi-skilled immigrant labour (largely from poorer countries of the Indian subcontinent) helped to build the physical structures. This was a conscious policy process that was linked to modernising and growing the economy towards a regional and international hub (Davidson 2007).

Al-Ali (2008) contends that the Emirates' open economic policy and lightly regulated labour market, has long encouraged multinational corporations to settle in Dubai and this strategy has resulted in high dependence on expatriate workers which now account for over 90 per cent of the labour market (DLA Piper 2008) outnumbering citizens by five to one (Bladd, 2009).

According to the career literature, many of the workers in Dubai are self-initiated expatriates, meaning that they migrated on their own initiative (Lee 2005; Suutari and Brewster 2001). Al Ariss and Syed (2011) maintain that, thus far, the self-initiated expatriation literature has a shortfall with regard to those self-initiated expatriates who migrate from ethnic minorities in developing countries. However, in common with much of the self-initiated expatriate literature and the literature on careers and international assignments (Minbaeva and Collings 2013), their paper focuses on skilled migrants. Conversely, this paper focuses on vulnerable workers from developing countries including domestic workers and labourers who are generally low-skilled or unskilled. In the case of such workers, although they may self-initiate their expatriation to Dubai, their situations do not fit with the extant career or human resource management literature, particularly as they often migrate through third party agents who contribute to their vulnerability in various ways such as misinformation and exploitation (Vlieger 2012). 
To date, there has been a lack of focus on vulnerable workers in the HRM literature, particularly those situated in the Middle East. Consequently, this paper explores issues relating to the labour market and employment regulation in the UAE, particularly in Dubai, where we highlight how this market has been constructed through deliberate policy choices contributing to the vulnerability of workers at the bottom of what we refer to as a 'three tier employment structure'. At a time when there has been unprecedented political unrest in the Middle East (Lynch 2013) this situation has led to a lack of basic human rights and infrastructure that supports worker participation and engagement. These circumstances are particularly highlighted with regard to labour regulation where basic labour conditions are deemed to be illegal (such as trade unions and the right to strike) and where the UAE has not ratified some international standard labour rights including freedom of association (Davis 2006). As a consequence, a large component of the Dubai workforce are in vulnerable employment; that is they have diminished rights and conditions across a range of criteria including employment protection, bargaining rights, working conditions and voice (Pollert 2008; Pollert and Charlwood 2009). Therefore, it is proposed that an industrial relations/human resource management system may be developed from a situation where there are no collective rights or trade unions and a highly segregated labour market exists. Accordingly, this paper focuses on two research questions:

1 What changes to industrial relations (IR)/human resource management (HRM) policies and practices would improve conditions for vulnerable workers in Dubai?

2 What are the implications of such changes for HRM?

The first section of this paper examines labour regulation in Dubai, followed by a discussion concerning the role of migrant workers in the development of many resource rich economies. Next, the paper discusses the implications of introducing changes to the existing IR/HRM policies and practices in Dubai in order to reduce worker vulnerability. Finally, the implications of the proposed changes for IR/HRM are discussed with regard to both employees and employers and a framework is proposed that encompasses the impacts of globalisation, the responses required of strategic international HRM and proposed HR practices to reduce worker vulnerability.

\section{The Constructed Segmentation of the Dubai Labour Force}


While Dubai breaks a number of records for its large buildings and wealth, the same buildings have been constructed by migrant workers, many of whom receive very low wages. The main aim of most workers coming to Dubai was to be able to send money home. This can prove challenging, given that construction or the 'ordinary labour' category worker receives the lowest average monthly wages of all occupational groups in the UAE (Tanmia 2005). In fact, Dubai construction workers went on strike on 11 March, 2007 as they allegedly had not received a pay rise for 18 years in some cases (Kapiszewski 2006). On wages as low as 550 AED per month (A $\$ 216.25)$ these pay rates compare with the minimum wage for UAE nationals established in 2006 of 5000 AED (A\$1,916.27) for those with post secondary qualifications and 3000 AED for those with below secondary school qualifications. This equates to a pay differential of $\$ 1,700$ per month.

Apart from the social and economic problems that are commonly associated with low-wage migrant workers taking on dirty, difficult, dangerous, demeaning and unstable work that local employees do not want (Athukorala 2006; Cammett and Posusney 2010), the rapid development of Dubai has also come at a cost, given that within the construction sector alone, it is estimated that the number of deaths from industrial accidents was 880 in 2005 (Jacob 2008). A UK report associated the vulnerability of migrant workers with a lack of safety training, non-existent or inadequate safety clothing, and poor English language skills which lead to greater instances of illness, injury or even death at work (Anderson and Rogaly 2005).

Despite its rapid transformation, labour laws in the UAE have remained largely unchanged since 1980 and, to date, Dubai does not have in place the institutions or infrastructure that support and protect fundamental labour standards. A new draft labour law was constructed in 2007 and some changes were made to the 1980 law in 2010 (which are outlined later). However, Human Rights Watch (2007) commented that the proposed labour law falls far short of international standards for workers' rights, stating that it should be revised to protect workers' rights to organize, bargain collectively and strike, and to cover excluded groups such as domestic workers. The laws specify terms of recruitment, maximum working hours and age limits citing rights to annual leave, overtime, occupational safety measures and healthcare provided by employers. Moreover, while the 
UAE Ministry of Labor imposes the federal law, the individual Emirates can adopt their own agencies of enforcement, as in the case of Dubai where, although the law calls for a minimum wage, the Ministry of Labor has yet to adopt such a measure (Human Rights Watch 2011). Thus, although the UAE labour market generates approximately 300,000 new jobs each year and there are not enough locals to fill them, job seekers need to be aware that rights that they take for granted in their home country do not in general apply in Dubai (Davis 2006). For example, there are no anti-discrimination laws and employers can request applicants from a particular nationality.

It was noted in a 2007 workshop organised by the UAE Minister of State for Federal National Council Affairs (MSFNCA) that the lack of robust labour market data in the UAE is an obstacle to achieving consensus on problems and developing solutions for the region. Data that is available via the 2009 Dubai Labour Force Characteristics Survey (the latest offered) reveals that the total working population for that year comprised 1,352,248 with locals accounting for 41,778 and non-locals 1,310,470 workers (or 96.8 per cent). Table 1 illustrates the number of people employed in Dubai (15 Years and over) by nationality, gender and occupation for 2009. The major expatriate groups in the UAE by country and estimated numbers are India $(1.5 \mathrm{~m})$; Pakistan $(0.85 \mathrm{~m}$.) and Bangladesh $(0.8 \mathrm{~m})$ with the major expatriate group from Western nations is the UK $(0.24 \mathrm{~m})$ (Koji, 2011).

\section{(Table 1)}

At one extreme of this migrant workforce are professionals and expatriate workers (mainly from the UK, Germany and South Africa) filling positions in management, accounting, education, health, engineering and architecture. The majority of these workers have degrees from European, North American and Australian universities (Harvey and Groutsis 2012). They are employed under contract and require an identity card and visa in order to obtain employment. At the other end of the social and economic spectrum are vast numbers of semi-skilled workers in the construction, hospitality and domestic services industry (Stephenson and Ali-Knight 2010). They are predominantly Asian, and from India, Pakistan, Bangladesh, Indonesia, Thailand and the Philipines and include a growing number of domestic workers from Ethiopia (Fernandez 2010). Many are contracted to recruiting agents and, in the case of the construction sector, are housed in labour camps 
(Buckley 2012). The Khafala system of short term contract labour recruitment means that many migrant workers are caught in a system of few protections and extreme vulnerability (Fernandez 2010). Between repaying loans for relocation and deductions for living costs, such workers can find themselves destitute, and in some cases confined to camps, or in the case of domestic service workers, not allowed breaks or to leave the private houses they are employed in (Fernandez 2010). As a result, grievances have arisen with a series of unofficial strikes in the construction sector, prompting the government to intervene and deport trouble makers (Cammett et al. 2010). Trade unions, strikes and lock outs are prohibited, and the Dubai Ministry acts as an adjudicator in any contract dispute.

The segmentation of the labour force has been a deliberate policy strategy in Dubai (see table 2). At the top of the labour market stratum are the relatively small number of Emiratis who are entitled to extensive benefits and public sector employment (Davis 2006; Cammett et al 2010). In terms of expatriates, the elite are well paid professionals mainly from Europe and North America (Vora 2009). At the lowest level are service and construction workers from the Indian sub-continent and South East Asia. The latter group are generally a compliant and relatively low paid sub-stratum of workers that provide important services and infrastructure to the Emirate (Vora 2009). Despite an absence of labour rights, the regulations governing employment are extensive and cover the registration of expatriate workers and the content of the employment contract (Al Tamimi 2007). First, there are regulations governing UAE nationals employed in the public sector. Second, there are regulations governing expatriate and other workers. Thirdly, there are regulations governing domestic service workers. It is a social pyramid system, with the local Emirates' on the top and the non-skilled or semi-skilled (migrant workers) at the bottom (Hardy 2007). There are also regulations concerning special free trade zones that are exempt from labour law regulations or involve special conditions that only apply to the specified zones (Davis 2006).

\section{(Table 2)}

Finding meaningful employment for UAE nationals led to the introduction of the Emiritisation policy, which imposes quotas on sectors such as banking and insurance to ensure that they employ local staff (Tanmia 2005; Rees, Mamman and Braik 2007). UAE 
nationals working for the private sector are entitled to the same pension and social security benefits that they would receive working for the public sector (UAE Government Strategy 2007). Overall, the Emiratisation policy has been largely unsuccessful (Randeree 2009; AlWaqfi and Forstenlechner 2010). In 2006, over 52 per cent of the workforce was employed in the private sector with only 2 per cent comprising UAE nationals, confirming that most Emiratis consider public sector jobs to be the most desirable (Randeree 2009). That said there have been recent moves to revitalise the policy as the UAE Ministry of Labour recently announced that companies based in the UAE would be required to employ not less than 15\% of Emiratis as part of their workforce (Emri 2011). Quotas such as this are designed to counteract local unemployment which has been blamed on an influx of expatriate labour and the failure of plans to create more jobs for locals (Randeree 2009). However, the onset of the GFC and the growing number of graduates seeking jobs (particularly women) has seen unemployment rates of close to 25 per cent for young Emirati job seekers. The explanations are linked not only to the economic downturn, but to some negative views held by the private sector towards Emiratis regarding their attitudes and productivity, and the avoidance of lower paid and low-skill jobs by locals (Koji 2011).

Human Rights Watch (2010) claims that the GFC saw many construction workers sent home without payment. They also raised concerns over the treatment and conditions of female domestic workers in the UAE. Moreover, where labour standards do exist for migrant workers they are frequently difficult to enforce. For example, Hardy (2007) reports that there were only 240 labour inspectors at the time of writing and Jacob (2008) claims that there were over 100 suicides in the labour camps in 2007, in addition to a large number of deaths reported from industrial accidents in the construction sector. In 2007 poor living and working conditions, and the non-payment of wages contributed to growing labour unrest. These conditions led to a series of (illegal) strikes culminating in the deportation of some of the strikers (Verma 2007) and worker unrest continued into 2008 as the falling US dollar depleted their value savings and remittances (Jacob 2008).

Zachariah, Prakash and Rajan (2002) reported for the Indian state government of Kerala on the demand and conditions associated with immigrant labour from Kerala in Dubai, stating that one of the major problems was that workers were forced to agree to new contracts once they had arrived in the UAE. Further, the terms and conditions of 
employment they were promised by recruitment agencies in India were rarely met, passports were handed over on arrival and they were forced to sign agreements that paid lower wages and provided for fewer non-wage conditions than promised. Effectively, such workers had their 'new' contracts renegotiated from a position of extreme vulnerability (Zachariah, Prakash and Rajan 2002) as some of the workers cannot read so relied on trust when agents inform them of the conditions they would work and live under in Dubai. Allegedly, thousands of migrant workers, each paid more than A\$2,000 to employment agents in India and Pakistan and were promised double the wages they actually received, plus plane tickets to visit their families once a year. However, when they arrived (some after selling land or taking out large loans) they found that they had no access to healthcare and many other basic rights (Zachariah, Prakash and Rajan 2002).

As the employment regulation system does not enshrine fundamental labour standards and trade unions and collective bargaining and strikes are prohibited, employees must bargain directly with their employer over their terms and conditions of employment (Cammett et al. 2010). Migrant workers are denied any form of voice in the workplace, have no citizenship rights (Sater 2013) and are highly dependent on contractors and employment agents, many of whom have various forms of control over them such as holding their loans and passports (Rahman 2012). These factors raise the question as to why workers would come to Dubai in the first place. Nonetheless, Caplin (2009) points out that despite the hardships of Dubai's male migrant construction workers (many of whom work long hours under difficult conditions), they still benefit from living in a community of fellow migrants, whereas many female migrants who take up employment as domestic workers find themselves isolated, alone and sometimes abused.

Concern for domestic workers led to the International Labour Organisation (ILO 2011) adopting a new convention at its 100th annual meeting on 16 June 2011 at the Convention Concerning Decent Work for Domestic Workers. The ILO aims to protect the rights of domestic workers, its goal being to guarantee weekly days off, limit working hours, ensure a minimum wage and protect domestic workers from violent employers. This gives domestic workers the same rights and protections that apply to other workers. Many countries, including Dubai, have excluded domestic workers from the application of basic labour laws but the new convention, of which the UAE is a signatory, will remove the legal 
marginalisation of domestics from the regulatory system. Although it does not remove the potential risks associated with the short term contract and agency system, and it may promote more illegal arrangements, it does represent a move towards the normalisation of employment protection and entitlements for domestic workers (Varia and Becker 2012).

\section{Migration and Vulnerability}

Reviews of public policy and economic migration generally agree that within most countries it is confusing, complex and often contradictory (Martin 2003). Often migrant workers are excluded from benefits and protection, and subject to forms of exploitation including underpayment, long hours and poor working conditions (Ruhs 2003). Given the conditions linked to vulnerability, migrant workers are one of the most 'at risk' segments of the workforce (Jayaweera and Anderson 2008). This is also the case for nearly all programs based on temporary contracts that are related to migrant worker status (Ruhs 2003). In the midst of claims regarding skill shortages, in many of the advanced OECD economies there remain large flows of migration into low-skilled, low-paid and poorly protected jobs (Taran and Geronomi 2003).

Contracted migrant workers in Asia, Africa and the Middle East, including Dubai, tend to be subject to rigid controls over their labour contracts due to government restrictions on length of stay - usually two to three years - that disallow settlement for the migrant worker and their respective families (Shah 2006). Residency restrictions in some of the Gulf Cooperation (GCC) countries (Kuwait, Oman, Saudi Arabia and the United Arab Emirates) are a result of concern about the high numbers of migrant workers compared to locals - as pointed out previously (Kapiszewski 2006).

It is clear that labour immigration has been an integral part of the Dubai success story (Al-Ali (2007) where migrant workers have supplied both professional skills and filled low-paid jobs in construction and services. However, nearly all immigration to Dubai is short-term, transitory and limited to specific employment contracts (Baruah 2006). The recruitment and management of much of the migrant workforce is carried out by employment agents who are in the private sector and licensed in the country of recruitment. However, complaints have been directed against the employment agencies and contractors 
to whom they supply labour services including the misrepresentation of conditions, nonpayment of wages and the withholding of passports (McCormack 2012). A study of contract immigrants from the Philippines found that the complaints against recruitment agents included excessive fees, noncompliance with agreed employment contract conditions, contract substitution after arriving in the country of employment and disappearance after the collection of recruitment fees (Baruah 2006; Fernandez 2010).

There have been ongoing attempts to regulate employment agencies and it is clear that the country of employment is in the best position to regulate employment conditions (Gavel 2006). Recently, the Manpower Group, in conjunction with Verite, have produced a set of operational recommendations for protecting workers recruited across borders, particularly focusing on those labour market intermediaries that are directly involved in the movement of people. Referred to as an 'Ethical Framework for Cross-Border Labor Recruitment' the Framework is based on Manpower Group’s experience in cross-border recruitment and Verité's expertise in creating verification systems to protect human rights. The framework includes a system of verification and certification intended to leverage intervention from regulators, stakeholders, and other interested parties (McCormack, 2012).

\section{Is the Development of a Modern Economy Incompatible with an Effective System of}

\section{Labour Regulation?}

Rowley (2010) points out that the social and cultural edifice of a country is important for HRM including factors such as ethnicity, language, religion and beliefs. These factors are evident in the 'open and dynamic model of industrial relations' developed by Caspi and Kastiel (2006) with regard to industrial relations systems in the Middle East. Central to the model is the notion that 'the open system continuously interrelates with its surroundings, and most importantly, is influenced by elements in the external environment' (Caspi and Kastiel 2006, p. 207) and the key elements are:

a. external factors: the ruling ideology, social cohesion; tolerance; socio economic conditions; legal structure; economic conditions; the media; standard of living;

b. internal factors: trade unions, employer associations, government; 
c. industrial relations processes: collective bargaining; agreement making; agreement regulation; dispute resolution and

d. output: working conditions; wages; productivity; employment security and legitimisation.

Components of the open system ' $b$ to c' above comprise the standard components of industrial relations systems. There are similarities to the Dunlopian system of actors, rules and regulations and outputs (Michelson 2008). That is, a system of formal regulations and institutions set out the conditions of employment and establish a framework for bargaining between employers and employees. Caspi and Kastiel (2006) use this framework to review the industrial relations systems in a number of Middle Eastern countries. Of the countries reviewed, Saudi Arabia is closest to the model of Dubai, where there was rapid economic development following the discovery of oil, starting from a base of traditional agriculture and trading with a largely unskilled population. To meet the needs of rapid economic development the skills and workforce shortages were met by contract migrant labour. However, by the late 1990s the migrant workforce share of the total workforce was around $60 \%$, well below the $90 \%$ plus in Dubai. In Saudi Arabia the government completely regulated the industrial relations system. In common with Dubai, there are no trade unions, collective bargaining is prohibited, strikes are illegal and employers set wages. There is also a constructed segmented system with different rules applying to different forms of work (such as domestic help), different categories of workers (such as Emiratis) and to different industries and locations - in the case of Dubai, the free trade zones (Davis, 2006).

These are features shared by the Gulf States, with the rationale for the model of industrial relations being that it is best suited to a traditional form of society (Caspi and Kastiel 2006, p. 119). In Saudi Arabia there were, however, tentative steps towards the recognition of employee voice with the official validation in 2002 of employee committees in companies that employed more than 100 Saudi nationals (Alzalabani, 2004).

One of the main observations of Caspi and Kastiel (2006) is that external factors play a major role in shaping industrial relations systems. In particular, they claim that democracy and civil society go hand-in-hand, stating 'the essential characteristics of civil society are its structures of voluntary association, networks of public communication and 
norms of community cooperation' (p. 106). With a strong civil society, democratic institutions are allowed to develop. Where structures of civil society are weak and democratic structures poorly developed, then the industrial relations system will exclude forms of voice and collective participation, processes will be rigidly prescribed and outputs skewed towards employers and government (Delgado-Wise, Márquez Covarrubias and Puentes, 2013).

Table 3 summarises a number of the factors affecting the employment of migrant workers in Dubai. The table was constructed by drawing on key factors arising from the literature discussed thus far, in addition to key components of Caspi and Kastiel's (2006) model of industrial relations. Illustrated in the table are internal/external factors affecting the workforce; HR policies and practices concerning employees, employers and government in addition to proposed changes to IR/HRM policies and practices that would improve conditions for vulnerable workers in Dubai.

\section{(Table 3)}

\section{The implications of changes to IR/HRM policies and practices}

It is evident that, while expatriate labour has been one of the largest contributors of the outstanding economic growth that has occurred in Dubai and the UAE, there are some urgent issues that require attention with regard to the labour market and reforms in the labour law. For example, although it is illegal for employers to reduce pay and withhold passports, and for agents to take recruitment fees, this is reportedly still occurring, leaving migrant workers virtually shackled to their employers especially where labour contracts are being traded outside of the regulatory system (Fernandez 2010).

HR personnel and their respective organisations can help to develop strategies that will have a positive impact on the conditions workers find themselves working under. For example, in the capital of the UAE, the Abu Dhabi campus of New York University publicly committed to requiring all companies that were involved in constructing and operating its campus to reimburse any workers for recruitment, or any other employment related fees, they had paid to agents and similar. Their terms also banned employers from 
confiscating passports (HRW 2011) and the new Guggenheim Art Museum followed suit shortly afterwards. Although neither organisation has imposed any third party monitoring, attempted to lift bans on collective bargaining or tried to impose a minimum wage, it does not mean that this could not be part of their working agreements with contractors or their organisational HR policy. This may require HR Directors to work on these issues at an international level with their respective company’s global headquarters, NGOs or similar.

Waring (2010) notes that HR managers typically require a strong sense of cultural sensitivity, combined with an appreciation for the way in which markets are developing in Asia as well as being 'increasingly cognisant of developments in labour law as informal arrangements and managerial prerogative give way to regulation that is typically more protective of employee interests' (p.50). However, Alfouni et al's (2013) research comprising a survey of 85 HR managers in banks situated in 13 Arab Middle East (AME) countries (including the UAE) indicates that the profile of HR managers as strategic business advisors needs to accompany other workplace changes. The researchers investigated whether an HR value proposition model was pertinent for the AME countries and concluded that it was. Their results indicate that the HR manager surveyed had some difficulty with implementing western-based practices in the region, with constraints arising due to the 'idiosyncrasies of the local culture, patriarchy, Islam and particularly with regard to national employment regulations' (p.1925). Further, the surveyed HR managers reported that, in their workplaces there was an emphasis on rules and regulations, they had no involvement in designing business strategies and that there was a lack of employee empowerment within bureaucratic organizational structures. Given these findings, it appears that AME based HR managers are far from the strategic business partners and advisors advocated in westernised countries, indicating that a number of changes will be required for this to occur, including the empowerment of HR managers as well as workers in general.

Table 3 outlined a number of factors that affect migrant workers in Dubai that have been discussed in the paper thus far. Figure 1 focuses specifically on the implications of these factors for HRM, linking the impacts of globalisation with strategic HRM responses and the HR practices required to reduce migrant worker vulnerability in Dubai. 
Bewley and Forth (2010) argue that when certain features of the employment relationship tilt the balance of power in favour of the employer then the likelihood of adverse treatment is increased, whereas when the balance of power is tilted in favour of the employee, then it is reduced. Vulnerability covers a range of criteria including pay, employment conditions, job and income security, representation and bargaining rights as well as access to forms of protection and support including workers compensation and pension rights (Saunders 2003, 2006).

In Dubai, vulnerability in employment is primarily evident in one component of the migrant workforce that is confined to a number of low-paying occupations and sectors. These workers are treated very differently under labour legislation when compared to local Emirati and expatriate professional workers. Thus, it is suggested that, as illustrated in Figure 1, human resource managers and professionals need to work to make their roles more strategic and this will require; the management of talent management on a global basis; ensuring that local labour laws are complied with; the monitoring of HR practices as outlined here; managing relationships with recruiting agents (possibly through the use of the Ethical Framework for Cross-Border Labor Recruitment suggested by McCormack, 2012); ensuring that corporate social responsibility is exercised both within the organisation and through stakeholders (i.e. through supply chains) and making an effort to share responsibility for ensuring safe and dignified work practices (Lucas, Kang and Li, 2013).

If they operate as strategic business partners, HR managers and professionals can work to ensure that their organisations introduce minimum standards for their workers, particularly with regard to ensuring that safety standards and minimum wages are adhered to, and that the provision of breaks, leave and suitable accommodation are provided while working to improve employee participation and empowerment through providing 'voice mechanisms' and employee representation. Although a number of the factors (such as trade unions) outlined in table 3 are beyond the control of HR managers and professionals and require changes to the Labour Law, most practices and strategic IHRM initiatives are not. However, they will require changes to the workplace culture and recognition that workers' rights are critical, not just for their wellbeing but also for the organisation. For example, Kucera (2008) found that there was a direction association between trade union rights, democracy and export performance. Kucera (2008) suggests that this is because strong 
civil rights strengthen economic and social stability, and in turn, this positively impacts on trade performance. He also cites cross-country evidence indicating that democratic and civil rights are able to stabilise economic performance and therefore better deal with economic shocks.

\section{(Figure 1)}

That said it seems there is an indication that some larger scale changes could be introduced that will benefit the vulnerable, migrant workers based in Dubai given a number of reports and projects that have recognised their plight. Firstly, in 2007 the UAE Ministry of Labour released a report that highlighted respect for labour rights and the need to meet challenges posed by the economic boom and demographic structural changes occurring in the UAE. The report states that the UAE believes human beings have a right to decent living conditions and broad safety standards (UAE Ministry of Labour 2007). Further, the report acknowledges that there is much to be done to expand the capacity to enforce labour laws and fully protect the rights of workers in the country. Although this was presented as an annual report, there does not appear to have been a more recent report published to date.

Secondly, following the publication of the 2007 report on Labour Rights, the UAE hosted the "Gulf Forum on Temporary Contractual Labor" where it was agreed to enhance partnerships between countries of origin and destination with regard to UAE migrant labour. Thirdly, following this forum in 2008, the UAE, the Philippines and India launched a pilot project to improve the quality of life for migrant workers with the intention that workers are supported throughout their experience through practical measures to improve recruitment and "pre-deployment” before arrival; improved living and working conditions in the UAE; and steps to facilitate the return and reintegration of workers to their home country. The focus was on workers in the construction, hospitality and health care sectors, while emphasising the vulnerabilities of women in all phases of the employment cycle. This project reportedly began in 2010 comprising migrant workers from India and the Philippines Agunias and Newland (2012) but the outcomes do not yet appear to be publicly available. In the meantime, HR personnel could be encouraged to work on the activities outlined in the pilot project and/or encourage their organisations to support the 
improvement of migrant recruitment and deployment before arrival and their living and working conditions as well as assisting with reintegration when they return home.

Fourthly, the Arab Employment Forum (2009) developed the Arab Action for Employment Jobs Pact for Recovery and Growth which includes nine points related to the strengthening of international labour standards and workers' rights and called on the Arab Labour Organisation (ALO) and the International Labour Organisation (ILO) to continue to work to follow up initiatives with regard to the Decent Work Country Programs. As Caplin (2009) points out though, while the UAE ratified six of the eight central ILO conventions it has not ratified the conventions which provide for the Freedom of Association, Protection of the Right to Organise and Collective Bargaining.

An important external factor in the UAE is the dependence on migrant workers who are excluded from civil institutions. When a strong civil society exists then democratic institutions are allowed to develop (Delgado-Wise, Márquez Covarrubias and Puentes, 2013) but where they are weak and democratic structures poorly developed, then the industrial relations system will exclude forms of voice and collective participation, processes will be rigidly prescribed and outputs skewed towards employers and government. The Dubai media is censored by the government and thus would not be able to support or report on worker conditions unless approved by them and, as Davis (2006) notes, there is an unwritten contract between the ruling elite and nationals that guarantees jobs and social transfers for nationals in exchange to acquiescence and support to the status quo.

If changes in the Dubai labour reforms continue and are implemented and enforced, it may be seen that economic growth and a fair and just system for all workers can indeed be compatible with economic growth. There appears to be an emerging labour code that indicates positive improvement where public policy is directed at developing policies for the optimal organization of the workforce. This includes determining minimum standards for the work environment, in terms of health and safety and living standards along with inspection and monitoring systems that safeguard the rights of all parties (as outlined in the UAE Government Strategy 2007). Further progress toward workers’ organising rights will need to come from within the countries themselves, although the authoritarian climate is a 
major constraint and 'labor repression is part of the broader problematic regime of stability and change in the Arab world' (Cammett et al. 2010, p.276).

\section{Conclusion}

Recent political turmoil in the Middle East has drawn attention to the absence of political and labour rights throughout the region (ILO 2011). Further external pressures towards reforms are associated with the pursuit of bilateral free trade agreements undertaken by the UAE, with important agreements with the EU and the USA being dependent upon encoding basic labour standards (Koji 2011). With such a large and culturally diverse workforce and the continuing (if slightly slowing) economy in Dubai this is an issue that requires ongoing monitoring and attention before any real improvements are evident.

This paper focused on two research questions:

1 What changes to industrial relations/human resource management policies and practices would improve conditions for vulnerable workers in Dubai?

2 What are the implications of such changes for human resource management?

In response to question one a proposed agenda set out the rationale for the development and application of core labour conditions, highlighting the association between these conditions and economic development. Factors relating to the proposed changes are illustrated in table 3.

Dubai has developed a centrally regulated employment system that systematically segregates the workforce and excludes basic labour rights. However, unlike many developing economies, Dubai did not possess a large stock of surplus labour when setting out on a growth trajectory. As a result, a deliberately constructed employment system was developed that limits the institutional building that supports growth and civic institutions. Within this system a large component of the workforce are employed under vulnerable employment conditions. Not only does the current system disallow these workers from 
access to fundamental labour rights it highlights the absence of key institutions that can support growth and inclusion.

Having constructed the present employment system, the Dubai government is in a good position to develop the institutions and conditions that support change. The ILO (2012) commented on political unrest in the Middle East and North Africa, stating that uprisings have resulted from poverty, inequality and exclusion due to deficits in democratic governance, freedom and social dialogue. While the current situation is not ideal, the spotlight on the UAE and Dubai in terms of human rights and expatriate labour, along with the apparent desire of the government to improve working and living conditions, is a step in the right direction. With such a large and culturally diverse workforce and the continuing (if slightly slowing) growing economy in Dubai this is an issue that requires ongoing monitoring and attention before any real improvements are evident. Given the number of migrant workers based in Dubai there are a number of challenges involved. However, employing expatriate HR personnel who may have operated as 'strategic business partners' in the past and have the experience and knowledge of protective labour laws and conditions that benefit employees in other countries may benefit workers in the UAE as outlined here.

In summary, this paper has accentuated the role that IR/HRM can play in influencing the improvement of workplace conditions for vulnerable workers, particularly with regard to the introduction of minimum standards relating to workplace safety, minimum wages, leave and accommodation even within an authoritarian culture. If labour reforms do take place in Dubai as Waring (2010) points out, HR managers will need to be 'increasingly cognisant of developments in labour law as informal arrangements and managerial prerogative give way to regulation that is typically more protective of employee interests' (p.50).

In summary, it is recognised that this paper has some limitations as it is based on secondary data and literature. However, it is proposed that the literature engaged with, and the propositions made, assist in advancing this important issue where further work needs to be undertaken in the future. Although it is recognised that there may be some difficulties, due to potential restrictions in the region, it is suggested that it would be beneficial for future researchers to endeavour to conduct empirical work not only with HR managers but with groups of vulnerable migrant workers. Such studies could help to identify best 
practices in the region as well as establish whether the initiatives outlined earlier, such as the pilot project to improve the quality of work for migrant workers, have made a difference to the conditions outlined in this paper. 


\section{References}

Abdulla, J., Djebarni, R., and Mellahi, K. (2011), 'Determinants of Job Satisfaction in the UAE: A Case Study of the Dubai Police’, Personnel review, 40(1), 126-146.

Afiouni, F., Karam, C., and El-Hajj, H. (2013), 'The HR Value Proposition Model in the Arab Middle East: Identifying the Contours of an Arab Middle Eastern HR Model, The International Journal of Human Resource Management, 24(10), 1895-1932.

Agunias, D. R., and Newland, K. (2012), 'Labour Migration from Colombo Process Countries: Good Practices, Challenges and Ways Forward, Issue in Brief', A Joint Series of the IOM Regional Office for Asia and the Pacific and the Migration Policy Institute: International Organisation for Migration.

Al-Ali, J. (2008), 'Emiratisation: Drawing UAE Nationals into their Surging Economy', International Journal of Sociology and Social Policy, 28(9/10), 365-379.

Al-Hamadi, A. B., Budhwar, P. S., and Shipton, H. (2007), 'Management of Human Resources in Oman', The International Journal of Human Resource Management, 18(1), 100-113.

Al Rajhi, A., Al Salamah, A., Malik, M., and Wilson, R. (2012), Economic Development in Saudi Arabia, Saudi Arabia: Routledge.

Al Tamimi \& Company. (2012), 'Labour Law in the UAE',

http://www.aluminium.gl/sites/default/files/12_PDF/arbejdskraft/UAE\%20-

\%20Appendix\%201\%20Labour\%20Law\%20in\%20the\%20UAE.pdf

Al-Waqfi, M., \& Forstenlechner, I. (2010). Stereotyping of citizens in an expatriatedominated labour market: Implications for workforce localisation policy. Employee Relations, 32(4), 364-381.

Alzalabani A. (2004), 'Industrial Relations and Labour Market in Saudi Arabia', Paper Presented at the $\mathrm{Conference}$ of the International Industrial Relations Association (IIRA), Seoul, Korea, 23- 26 June.

Anderson, B and Rogaly, B. (2005), 'Forced Labour and Migration to the UK', http://www.tuc.org.uk/international/tuc-9317-f0.cfm/accessed 23/6/2011.

Arab Employment Forum (2009), 'A Jobs Pact for Recovery and Growth', http://www.ilo.org/public/english/region/arpro/beirut/aef/.

Athukorala, P. (2006), International Labour Migration in East Asia: Trends, Patterns and Policy Issues, Canberra: Asia Pacific School of Economics and Government, The Australian National University and Blackwell Publishing Asia. 
Baruah, N. (2006), 'The Regulation of Recruitment Agencies: Experience and Good Practices in Countries of Origin in Asia', in International Institute of Labour Studies, ed. C. Kaptsch, pp.37-46.

Bewley, H., and Forth, J. (2010), 'Vulnerability and Adverse Treatment in the Workplace', http://www.cardiff.ac.uk/cglr/events-activities/2010/bewley-forth.pdf .

Bladd, J. (2009), 'Expat Workforce is GCC's Biggest Issue',

http://www.arabianbusiness.com/expat-workforce-is-gcc-s-biggest-issue-ex-wto-chief$\underline{12340 . h t m l .}$

Buckley, M. (2012), 'Locating Neoliberalism in Dubai: Migrant Workers and Class

Struggle in the Autocratic City’ Antipode, Wiley Online Library.

Budhwar, P. S., and Mellahi, K. (2006), (eds.), Managing Human Resources in the Middle East. Routledge.

Cammett, M and Posusney, M. (2010), 'Labor Standards and Labor Market Flexibility in the Middle East: Free Trade and Freer Unions?', 45 Studies In Comp. Int'l Dev, 250, 260.

Caplin, J. (2009), 'Mirage in the Desert Oasis', Harvard International Review, 30(4), 2832.

Caspi, A. and Kastiel, R. (2006), 'Industrial Relations in the Middle East', in Global Industrial Relations, eds. M. Morley, P. Gunnigle and D. Collings, Oxford: Routledge, 106-123.

Connell, J. and Thorpe, M. (2010), 'Regional Development and the "Dubai Model”: Some Observations and Experiences', in Business Clusters, Partnering for Strategic Advantage, eds. C. Jayachandran, M. Thorpe, R. Subramanian and V. Nagadevera, New Delhi/Oxford: Routledge, 231 - 259.

Davidson, C. (2007), 'The Emirates of Abu Dhabi and Dubai: Contrasting Roles in the International System', Asian Affairs, 38(1), 33-48.

Davis, M. (2006), 'Fear and Money in Dubai' New Left Review, 46 (September-October), 47-69.

Delgado-Wise, R., Márquez Covarrubias, H., \& Puentes, R. (2013), 'Reframing the Debate on Migration, Development and Human Rights', Population, Space and Place, 19: 430-443. doi: 10.1002/psp.1783

DLA Piper (2008), Employment Law Supplement for the Middle East, October.

Economist, (2011), 'Free the Maids, A New Treaty Aims to Stop Abuse', http://www.economist.com/node/18866759. 
Emri, A, (2011), UAE: Curiosity - Government Official Proposes Quota System for Foreign Workforce in Dubai. http://www.moveoneinc.com/immigration/enuaecuriosity-government-official-proposes-quota-system-foreign-workforce-dubai accessed 2/8/2011

Fernandez, B. (2010), 'Cheap and Disposable: The Impact of the Global Financial Crisis on the Migration of Ethiopian Women Domestic Workers to the Gulf', Gender and Development, 18(2), 249-262.

Gavel, E. (2006), 'ILO Labour Standards Concerning Labour Services', in Merchants of Labour ed. C. Kaptsch (Ed), Geneva: International Institute of Labour Studies, 145154.

Hardy, F. (2007), 'Labour Protests in Dubai', http://global-labour-issues.suite 101.com/article.cfm/labor_protests_in_Dubai .

Harvey, W., \& Groutsis, D. (2012), 'Skilled Migrants in the Middle East: Definitions, Mobility and Integration, International Journal of Business and Globalisation, 8(4), 438-453.

Human Rights Watch (2007), 'The UAE Draft Labor Law: Human Rights Watch and Recommendations', http://www.hrw.org/en/reports/2007/03/25/uaes-draft-labor-lawhuman-rights-watch-s-comments-and-recommendations accessed 2/8/2011

Human Rights Watch (2010), 'Country Summary: United Arab Emirates', http://www.hrw.org/world-report-2010/united-arab-emirates-uae

Human Rights Watch (2011), 'World Report 2011', http://www.hrw.org/en/world-report2011 .

Hvidt, M. (2011), 'Economic and Institutional Reforms in the Arab Gulf Countries', The Middle East Journal, 65(1), pp.85 - 103.

International Labour Organisation (2011) 'ILO Adopts Convention Concerning Decent Work for Domestic Workers', http://www.ilo.org/wcmsp5/groups/public/@ed_norm/@relconf/documents/meetingdoc ument/wcms_157836.pdf accessed 2/8/2011.

International Labour Organisation (2011), 'Questions and Answers on the ILO Response to Challenges in the Arab World', http://www.ilo.org/global/about-the-ilo/press-and,edia-centre/insight/WCMS_1594.

Jayaweera, H., \& Anderson, B. (2008). 'Migrant Workers and Vulnerable Employment: A Review of Existing Data', London: Mondon Report for TUC Commission on Vulnerable Employment. 
Jacob, C. (2008), 'Slave Labour in Dubai's Building Boom' http://news.sky.com/skynews/home/sky-news-archive/article/20080641281723 .

Kapiszewski, A., ‘Arab Versus Asian Migrant Workers In The Gcc Countries’, United Nations Expert Group Meeting On International Migration And Development in the Arab Region, Population Division, Department of Economic and Social Affairs, United Nations Secretariat Beirut, 15-17 May 2006.

Khan, S. A. (2010), 'Convergence, Divergence or Middle of the Path: HRM Model for Oman', Journal of Management Policy and Practice, 12(1), 76-87.

Koji, H. (2011), 'Controversies Over Labour Nationalisation Policies and its Dilemmas: Forty Years of Emeritisation in the UAE'. Kyoto Bulletin of Islamic Area Studies, 4(1), $41-61$

Kucera, D. (2008), 'Trade Union Rights and Trade Competitiveness: Asia in a Global Context', in Globalisation, Flexibilisation and Working Conditions in the Asia Pacific, eds. S. Lee and F. Eyraud, Oxford: Chandos, 47-80.

Lee, C. H. (2005), 'A study of Underemployment Among Self-initiated Expatriates', Journal of World Business, 40 (2), 172 - 187.

Lee, S. and Eyraud, F. (2008), 'Globalisation, Institutional Reforms and Workers: Changes and Outcomes', in Globalisation, Flexibilisation and Working Conditions in the Asia Pacific, eds. S. Lee and F. Eyraud, Oxford: Chandos, 3-46.

Lucas, K., Kang, D., and Li, Z. (2013), 'Workplace Dignity in a Total Institution: Examining the Experiences of Foxconn's Migrant Workforce’' Journal of Business Ethics, 1-16.

Lynch, M. (2013), 'The Arab Uprising: The Unfinished Revolutions of the New Middle East', Public Affairs Store.

Martin, P. (2003), 'Managing Labor Migration: Temporary Worker Programs for the $21^{\text {st }}$ Century’, http://www.ilo.org/public/english/bureau/inst/download/migration3.pdf .

McCormack, J. (2012), 'An Ethical Framework for Crossborder Labor Recruitment', Manpower, Fourth Annual Interdisciplinary Conference on Human Trafficking, University of Nebraska - Lincoln.

Michelson, G. (2008), 'New Actors in Australian Employment Relations', in New Employment Actors: Developments from Australia, eds. G. Michelson, S. Jamieson and J. Burgess, Bern: Peter Lang, 19-42.

Minbaeva, D., \& Collings, D. G. (2013), 'Seven myths of global talent management' The International Journal of Human Resource Management, 24(9), 1762-1776. 
Moideenkutty, U., Al-Lamki, A., \& Murthy, Y. S. R. (2011), HRM Practices and Organizational Performance in Oman, Personnel Review, 40(2), 239-251.

Pollert, A. (2008), 'The Experience of Unorganised and Vulnerable Workers', Bristol: Centre for Employment Studies Research, Bristol Business School.

Pollert and Charlwood (2009), 'The Vulnerable Worker in Britain and Problems at Work', Work, Employment and Society, 23(2), 343-362.

Randeree, K. (2009), Strategy, Policy and Practice in the Nationalisation of Human Capital: Project Emiratisation, Research and Practice in Human Resource Management, 17(1), $71-91$.

Rahman, M. M. (2012), 'Bangladeshi Labour Migration to the Gulf States: Patterns of Recruitment and Processes', Canadian Journal of Development Studies/Revue canadienne d'études du développement, 33(2), 214-230.

Rees, C. J., Mamman, A., and Braik, A. B. (2007). 'Emiratization as a Strategic HRM

Change Initiative: Case Study Evidence from a UAE Petroleum Company', The International Journal of Human Resource Management, 18(1), 33-53.

Rowley, C. (2010), 'Contemporary Issues in HRM in the Asia Pacific Region: An Explanatory Framework', in eds. J. Connell and S. Teo, Contemporary Issues in Strategic HRM: An Asia Pacific Perspective, Tilde University Books, Melbourne. 22-44.

Ruhs, M. (2003), ‘Temporary Foreign Worker Programs: Policies, Adverse Consequences and the Need to Make Them Work', Perspectives on Labour Migration Program, Paper no 6, Geneva: ILO.

Sater, J. (2013). Citizenship and Migration in Arab Gulf Monarchies. Citizenship Studies, (ahead-of-print), 1-11.

Saunders, R (2003), Defining Vulnerability in the Labour market. Canadian Policy Research Network. Ottawa.

Saunders, R. (2006), Risk and Opportunity: Creating Jobs for Vulnerable Workers. Canadian Policy Research Network. Ottawa.

Shah, N. M. (2006), 'Restrictive Labour Immigration Policies in the Oil-Rich Gulf: Effectiveness and Implications for Sending Asian Countries', United Nations Expert Group on Social and Economic Implications of Changing Population Age Structure, United Nations Secretariat, Mexico City, 31 August - 2 September, 2005. 
Stephenson, M. L., \& Ali-Knight, J. (2010), 'Dubai's Tourism Industry and its Societal Impact: Social Implications and Sustainable Challenges. Journal of Tourism and Cultural Change, 8(4), 278-292.

Suutari, V and Brewster, C., (2001), 'Making their Own Way: International Experience Through Self-initiated Foreign Assignments', Journal of World Business, 35(4), 417436.

Tanmia, (2005), 'United Arab Emirates Human Resources Report', Dubai: Trident Communications.

Tanmia, (2006), 'The National Human Resource Development and Employment Authority, United Arab Emirates', http://www.tanmia.ae .

Taran, P. and Geronomi, E. (2003), 'Globalisation, Labour and Migration: Protection is Paramount', Perspectives on Labour Migration Program, Paper No 3E, Geneva: ILO.

Trade Union Council (TUC) (2008), Hard Work, Hidden Lives: The Full Report of the Commission on Vulnerable Employment. London: TUC.

UAE Government Strategy (2007), http://www.dubai.ae/en.portal?topic,hm_uaegovstrategy,1,\&_nfpb=true\&_pageLabel=2 (accessed December 2008)

. UAE Ministry of Labour (2007), 'The Protection of the Workers in the United Arab Emirates Annual Report', http://www.mfnca.gov.ae/en/Publications/TueJan2775844UTC2009attachments.pdf accessed 30/6/2013

Varia, N. and Becker, J. (2012), 'A Landmark Victory for Domestic Workers: New Convention Establishes First Global Labour Standards for Millions of Women and Girls'. Human Rights Watch, http:/www.hrw.org/world-report-2012/world-report2012-landmark-victory-domestic-workers, accessed 30/6/2013.

Verma, S. (2007), 'Dark Side of Dubai’s Economic Boom Exacts Harsh Human Toll', The Sunday Times, 3 November.

Vlieger, A. (2012). 'Domestic Workers in Saudi Arabia and the Emirates: Trafficking Victims?', International Migration, 50(6), 180-194.

Vora, N. (2009), 'The Precariousness of Dubai’s Indian Middle Class', Middle East Report, 252, 18-21.

Waring, P. (2010), 'Developments in Employment Relations in the Asia Pacific', in eds. J. Connell, J.and S. Teo, Contemporary Issues in Strategic HRM: An Asia Pacific Perspective, Tilde University Books: Melbourne, 45-58. 
Zachariah, K., Prakash, B. and Rajan, S. (2002), 'Gulf Migration Study: Employment, Wages and Working Conditions of Kerala Emigrants in the UAE', http://www.cds.edu/download_files/326.pdf accessed 3/12/2008 
Table 1: Total (15 Years and Over) by Nationality and Occupation - Emirate of Dubai (2009)

\begin{tabular}{|c|c|c|c|c|c|c|c|c|c|c|c|}
\hline Total & $\begin{array}{l}\text { Arm } \\
\text { ed } \\
\text { Forc } \\
\text { es }\end{array}$ & $\begin{array}{l}\text { Skilled } \\
\text { Agricul } \\
\text {-ture } \\
\text { And } \\
\text { fishery } \\
\text { workers }\end{array}$ & $\begin{array}{l}\text { Elemen } \\
\text { tary } \\
\text { Occupa } \\
\text {-tions }\end{array}$ & $\begin{array}{l}\text { Craft } \\
\text { And } \\
\text { Related } \\
\text { Worker } \\
\text { s }\end{array}$ & $\begin{array}{l}\text { Plant } \\
\text { And } \\
\text { Machine } \\
\text { Oper- } \\
\text { ators }\end{array}$ & $\begin{array}{l}\text { Service } \\
\mathrm{s} \\
\text { And } \\
\text { sales }\end{array}$ & Clerks & $\begin{array}{l}\text { Technicia } \\
\text { ns }\end{array}$ & $\begin{array}{l}\text { Professional } \\
\mathrm{S}\end{array}$ & $\begin{array}{l}\text { Legislators } \\
\text { and senior } \\
\text { Officials }\end{array}$ & $\begin{array}{l}\text { Nationalit } \\
\mathrm{y}\end{array}$ \\
\hline 44,321 & $\begin{array}{l}3,20 \\
6 \\
\end{array}$ & 179 & 764 & 406 & 238 & 5,621 & 7,833 & 10,687 & 9,098 & 3,746 & Local \\
\hline $1,310,470$ & 77 & 9,602 & $\begin{array}{l}417,56 \\
8 \\
\end{array}$ & $\begin{array}{l}264,93 \\
1\end{array}$ & 112,257 & $\begin{array}{l}148,52 \\
4\end{array}$ & $\begin{array}{l}64,66 \\
9\end{array}$ & 129,886 & 123,205 & 39,751 & Non-local \\
\hline $1,352,248$ & $\begin{array}{l}3,28 \\
3 \\
\end{array}$ & 9,781 & $\begin{array}{l}418,33 \\
2 \\
\end{array}$ & $\begin{array}{l}265,33 \\
7\end{array}$ & 112,495 & $\begin{array}{l}154,14 \\
5 \\
\end{array}$ & $\begin{array}{l}72,50 \\
2\end{array}$ & 140,573 & 132,303 & 43,497 & Total \\
\hline
\end{tabular}

Source: Adapted from Dubai Statistics Centre - Labor Force Survey, 2009

Table 2: Dubai's Three Tier Labour Market

\begin{tabular}{|l|l|l|}
\hline Labour Market Tier & Category & Comments \\
\hline Tier 1 & Local Emiratis & $\begin{array}{l}\text { Quotas imposed on companies } \\
\text { to employ minimum of 15\% } \\
\text { locals (as per a new law } \\
\text { introduced in December 2010) }\end{array}$ \\
\hline Tier 2 & $\begin{array}{l}\text { High skilled migrants generally } \\
\text { enjoy much better working } \\
\text { conditions than tier 3, low } \\
\text { skilled migrants (Vora, 2009) }\end{array}$ \\
\hline Tier 3 & $\begin{array}{l}\text { Construction workers (listed as } \\
\text { elementary occupations in table } \\
1)\end{array}$ & $\begin{array}{l}\text { Usually from South Asia } \\
\text { approximately 42.5\% of the } \\
\text { UAE's workforce }\end{array}$ \\
\hline $\begin{array}{l}\text { Domestic workers (mainly } \\
\text { female) }\end{array}$ & \\
\hline
\end{tabular}


Table 3: Factors Affecting the Employment of Expatriate Workers in Dubai

\begin{tabular}{|c|c|c|}
\hline Internal/External Factors & $\begin{array}{l}\text { HR Policies and Processes } \\
\text { Affecting Dubai Workplaces }\end{array}$ & $\begin{array}{l}\text { Issues for Employees, } \\
\text { Employers and Government }\end{array}$ \\
\hline $\begin{array}{ll}\text { External Factors } \\
\text { - } & \text { Islam } \\
\text { - } & \text { Culture } \\
\text { Curbs on naturalization } \\
\text { and citizenship rights } \\
\text { - } \quad \text { Government Regulations } \\
\text { High Labour Force } \\
\text { - } \quad \text { Growth Rates } \\
\text { Socio-economic } \\
\text { - } \quad \text { Characteristics/cohesion } \\
\text { - } & \text { Quality of Life } \\
\text { - } & \text { The Media } \\
\text { - } & \text { Economic conditions } \\
\text { - } & \text { Political system } \\
\text { - } & \text { Ruling ideology } \\
\text { Economic structure } \\
\text { - } & \text { Legal structures } \\
\text { Internal Factors } \\
\text { - } & \text { Trade Unions (none, } \\
\text { - } & \text { illegal) } \\
\text { Employer organisations } \\
\text { Government involvement } \\
\text { Gigh level of influence) }\end{array}$ & $\begin{array}{l}\text { Emiratisation Policy to increase } \\
\text { levels of Emirati employment } \\
\text { Sponsorship system for direct } \\
\text { expatriate recruitment } \\
\text { Agent intervention in cross-border } \\
\text { recruitment of low skilled workers } \\
\text { Contract employment for } \\
\text { expatriates (approx. } 3 \text { years) } \\
\text { Rotational system of expatriate } \\
\text { labour to limit duration of } \\
\text { foreigners' stay not effective as } \\
\text { employers usually prefer to keep } \\
\text { workers who have already gained } \\
\text { some local experience and do not } \\
\text { incur costs to bring them to Dubai } \\
\text { Kapiszewski. Increasing numbers of } \\
\text { 'almost permanent' workers (Ali, } \\
\text { 2010) } \\
\text { Collective bargaining) - not } \\
\text { applicable } \\
\text { Conflict resolution - not applicable }\end{array}$ & $\begin{array}{l}\text { Employees subject to: } \\
\text { Lack of minimum standards } \\
\text { regarding working conditions } \\
\text { Employment security may not be } \\
\text { different to home country but } \\
\text { could be additional problems if } \\
\text { overstay visa, sacked or 'locked } \\
\text { out' of workplace. } \\
\text { Potential Benefits } \\
\text { Compensation - tax free salary } \\
\text { Ability to send money home } \\
\text { Fast track career (particularly } \\
\text { those in tier 2) } \\
\text { Employers need to: } \\
\text { Empower workers at all } \\
\text { - } \quad \text { levels } \\
\text { Develop an effective } \\
\text { workforce } \\
\text { Improve productivity, } \\
\text { efficiency } \\
\text { Government need to examine: } \\
\text { - } \\
\text { Labour regulation } \\
\text { Policy support } \\
\text { Monitoring employee } \\
\text { working conditions }\end{array}$ \\
\hline
\end{tabular}

Source; Caspi and Kastiel (2006); Kapiszewski (2006); Afiouni, F., Karam, C. M., \& El-Hajj, H. (2013) and others. 
Figure 1: The Impacts of Globalisation, Strategic IHRM Responses and HR Practices Required to Reduce Worker Vulnerability

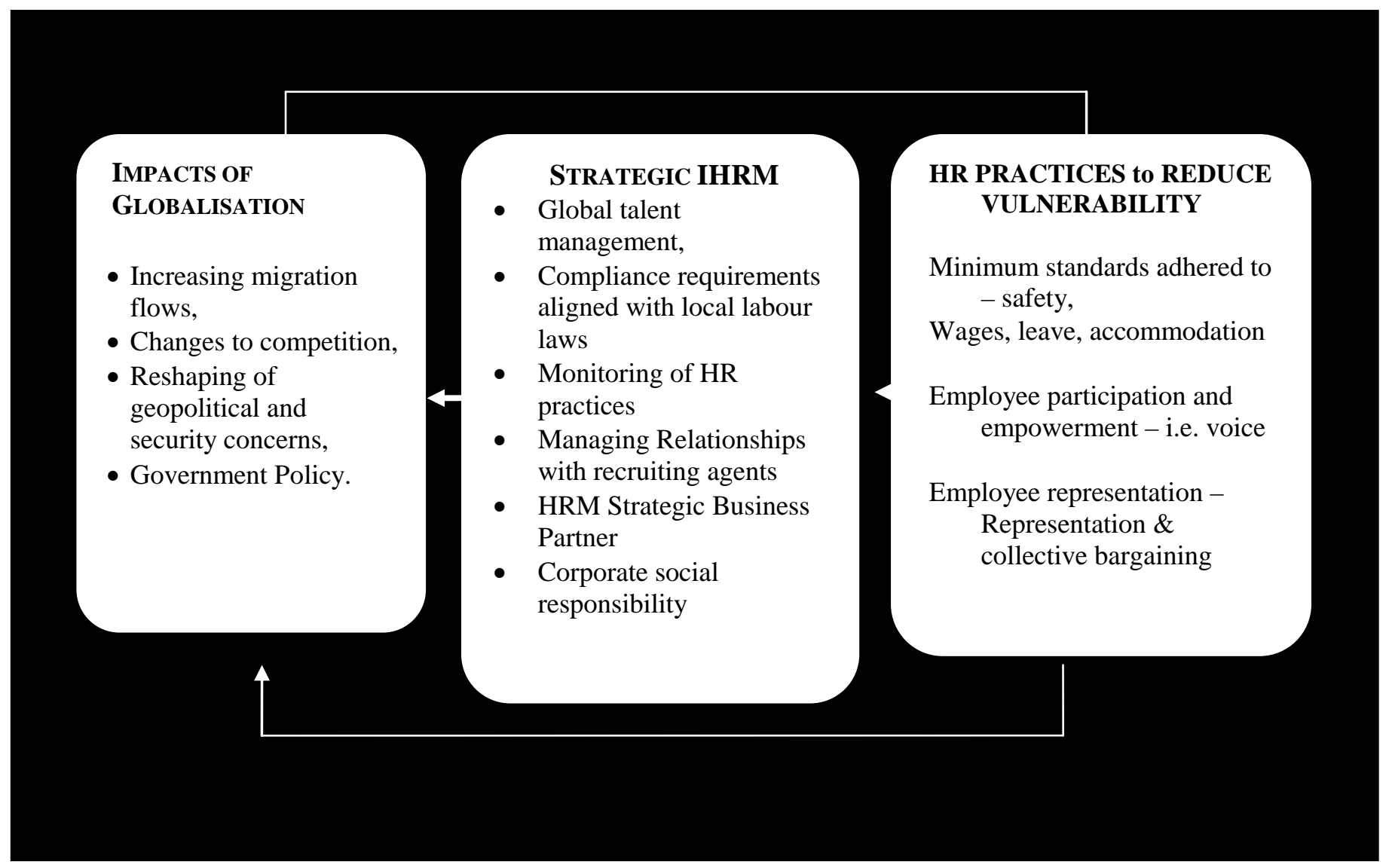

Source: Significantly adapted from Donnelly, N., and Dowling, P. (2010) 